\title{
Edukacja włączająca w perspektywie teorii waloryzacji ról społecznych
}

Głównym celem artykułu jest analiza teoretycznych założeń i praktycznych implikacji koncepcji edukacji włączającej przez pryzmat teorii waloryzacji roli społecznej. Teorię autorstwa Wolfa Wolfensbergera oraz jej pierwotną wersję - zasadę normalizacji uważa się za mające silny wpływ na rozwój i zmiany w zakresie systemów usług społecznych przeznaczonych dla osób z niepełnosprawnością, $\mathrm{w}$ tym szkoły i edukacji. W artykule uwzględniono punkty zbieżne między założeniami teorii waloryzacji roli społecznej oraz edukacji włączającej. Kluczowe pojęcia dla teorii Wolfensbergera takie jak wykluczenie, negatywne doświadczenia życiowe, dobra społeczne i 10 wątków przewodnich teorii zostały odniesione do inkluzji w edukacji uczniów o specjalnych potrzebach edukacyjnych. Poczynione interpretacje doprowadziły do wniosku, że mimo asymilacyjności wpisanej w teorię waloryzacji roli, proces, który opisuje może służyć polepszeniu społecznego oraz edukacyjnego funkcjonowania uczniów z niepełnosprawnością w szkołach ogólnodostępnych. Dysharmonie między tymi dwoma konstruktami teoretycznymi pozwoliły na uwidocznienie pewnych słabych punktów edukacji włączającej, a szczególnie sztywne, funkcjonalistyczne ujmowanie roli ucznia, ukrytą dynamikę wykluczenia oraz rozbieżność między wartościowaniem różnorodności a adaptacją do norm zastanych.

Słowa kluczowe: teoria waloryzacji ról, edukacja włączająca, role społeczne, wykluczenie

\section{Inclusive education in the perspective of Social Role Valorization theory}

The main aim of the article is to take a look at theoretical assumptions and practical implications of inclusive education concept through the perspective of Social Role Valorization theory (SRV). Wolfensberger's theory and its predecessor, the principle of normalization, are acknowledged as having major positive impact on human services, including education. The article analyses the main common points between theoretical frameworks of SRV and inclusive education. Crucial notions of SRV such as devaluation, wounds, good things in life and 10 themes have been related to inclusive education of children with special needs. These interpretations have led to the conclusion that in spite of adaptive nature of role valorization process it can be applied to enhance social and educational performance of disabled children in inclusive schools. Collision of these two theories unmasked some weak points of inclusive education, especially in the context of societal standards, hidden dynamics in devaluation creation, and some radical parts of SRV which do not fit in a diversifying society.

Keywords: Social Role Valorization, inclusive education, social roles, devaluation 


\section{Wprowadzenie}

Edukacja włączająca jest współcześnie traktowana jako koncepcja teoretyczna, jak i rozwiązanie praktyczne, którego żadna inna idea edukacyjna nie jest $\mathrm{w}$ stanie wyprzeć $\mathrm{w}$ sensie udowodnienia wyższej efektywności w rozwiązywaniu problemów dotychczasowych modeli kształcenia specjalnego, zbieżności z uniwersalnymi wartościami humanistycznymi czy trendami socjalizacyjnymi, jak np. zwiększająca się populacja uczniów o specjalnych potrzebach edukacyjnych. Edukacja włączająca jest aktualnie głównym politycznym imperatywem reformowania systemów kształcenia w krajach całego świata zapoczątkowanym w latach 90. XX wieku. W ogólnej definicji traktuje się ją jako radykalne, demokratyczne, zorientowane na "społeczną sprawiedliwość", podejście w tworzeniu, rozwijaniu i wspieraniu opartych na doświadczeniach, wolnych od uprzedzeń wspólnot edukacyjnych. Eliminując wszelkie bariery wspierają one wszystkich swoich członków bez względu na różnice tożsamościowe w rozwoju i uczeniu się [Gause 2011, s. 10].

Mimo ponad 25-letniej tradycji, a także powszechnego zasięgu koncepcja edukacji włączającej boryka się z niespójnościami definicyjnymi, brakiem konsensusu odnośnie do praktycznych jej wersji oraz niejednokrotnie jałowymi sporami o zasadność zastępowania tym modelem systemów wcześniejszych. Co być może rozczarowujące, nie rozstrzyga także jednoznacznie problemu odrębności kształcenia osób niepełnosprawnych. Praktyczny wymiar edukacji włączającej jako pierwotny wobec jej teoretycznych odniesień traci jednak na harmonijności, w konsekwencji - efektywności, jeśli w warstwie koncepcyjnej brakuje odpowiedniej systematyzacji [por. Szumski 2010, s. 39]. Z tym zadaniem mierzy się współcześnie pedagogika specjalna jako dziedzina naukowa, konfrontując fundamentalne dlań założenia (np. społeczny model niepełnosprawności, paradygmat normalizacyjny czy zasada indywidualizacji) z tezami koncepcji edukacji włączającej. Próbę takiej konfrontacji z rozwinięciem projektu normalizacji teorią waloryzacji ról społecznych - podejmuję w niniejszym artykule, za jego cel stawiając krytyczną refleksję nad walorami i ułomnościami edukacyjnego włączania jako jednej z dróg do społecznej integracji osób z niepełnosprawnościami.

\section{Od normalizacji do teorii waloryzacji ról - krótka charakterystyka ekspansji pojęcia}

Teoria waloryzacji ról $\mathrm{W}$. Wolfensbergera po raz pierwszy została opublikowana w 1983 r. i zyskała dużą popularność, szczególnie w amerykańskich publi- 
kacjach, w których uznano ją za jedną z najbardziej wpływowych z dziedziny nauk społecznych [Caruso, Osburn 2011, s. 47]. Powstała jako próba usystematyzowania istniejącej już od lat $60 . \mathrm{XX}$ wieku zasady normalizacji opracowanej przez N.E. Bank-Mikkelsena i B. Nirje [1969]. Według autorów normalizacja stanowiła proces przekształcania środowiska rehabilitującego w kierunku upodobnienia go do środowiska normalnego, konieczny ze względu na to, że oddziaływania specjalistycznych instytucji rehabilitacyjnych zniekształcają doświadczenia życiowe osób niepełnosprawnych już od początków ich życia. Główny przekaz zasady normalizacji, wysuwający się na plan pierwszy, to odejście od instytucjonalizacji $w$ opiece, rehabilitacji i edukacji osób z niepełnosprawnościami. W takim brzmieniu normalizacja miała ogromny wpływ na rozwój i zmiany w zakresie usług przeznaczonych dla osób niepełnosprawnych [por. Kumar, Theresiakutty 2012, s. 284] również, a może w szczególności, tych edukacyjnych [Kumar i in. 2015]. W miejscu "tworzenia normalnych warunków życia" dla osób niepełnosprawnych teoria ta łączy się z ideą edukacji włączającej, która za niezbywalne prawo każdego człowieka uznaje możliwość kształcenia się w publicznej szkole najbliższej miejsca zamieszkania, bez oderwania od lokalnej społeczności i „normalnej" codzienności [Kerzner, Lipsky, Gartner 1996, s. 763-767]. Przełożenie zasady normalizacji na różne płaszczyzny funkcjonowania osób niepełnosprawnych doprowadziło do jej idiosynkratyczności, a w konsekwencji nieporozumień i niespójności terminologicznych [Perrin, Nirje 1985; Caruso, Osburn 2011, s. 49]. Sam termin "normalizacja” bywał interpretowany bardzo powierzchownie, potocznie oraz w sposób uproszczony jako „unormalnienie" osób niepełnosprawnych (choć i dziś w takiej wykładni zdarza się występować).

Koherentnym podejściem kontynuującym myśl normalizacji, jednocześnie pozbawionym nieścisłości miała być wspomniana teoria waloryzacji ról Wolfensbergera (SRV - Social Role Valorization). Według definicji z 2005 r. stanowi ona formalne i nieformalne działania mające na celu umożliwienie pełnienia cenionych społecznie ról osobom wykluczonym z udziału w życiu społecznym lub zagrożonych wykluczeniem [Wolfensberger, Thomas 2005]. W efekcie wieloletniej pracy nad rozbudową i systematyzacją zasady normalizacji powstała teoria w niewielkim stopniu przystająca do swoich pierwotnych założeń [Kumar i in. 2015]. Jedna z różnic wskazuje, iż w kontekście społecznej inkluzji normalizacja jest osobie niepełnosprawnej dana (normalne warunki życia, prawa, obowiązki), natomiast waloryzacja roli oznacza osiąganie pewnych umiejętności, nawyków, zachowań, zanim osoba niepełnosprawna $\mathrm{w}$ pełni wejdzie w środowisko społeczne. Sam Wolfensberger zauważywszy więcej punktów wspólnych swojej teorii z teorią ról społecznych niż z normalizacją, od której wychodził, nadał jej nową nazwę [Lemay 1999, s. 219]. 
Podstawowe założenie teorii waloryzacji roli zasadza się na przekonaniu, że osoba, która realizuje role cenione społecznie, łatwiej osiąga pewien dobrostan (the good things in life) określony takimi wyznacznikami, jak: rodzina, przyjaciele, dom, praca, zdrowie, uczestnictwo w życiu społecznym, szacunek, szanse rozwoju itd. [Race 1999, s. 97]. W odniesieniu do osób niepełnosprawnych, jako znajdujących się $w$ grupie ryzyka ulegania społecznej dewaluacji, istotnym pojęciem $w$ teorii są negatywne doświadczenia życiowe (wounds): odrzucenie, niekorzystny wizerunek społeczny, segregacja, instytucjonalizacja życia, bieda, złe traktowanie: przemoc, brutalność itp. [Armstrong 2006, s. 2]. Jako antidotum na te doświadczenia i pierwotne wobec nich wykluczenie społeczne, Wolfensberger przedstawia waloryzację ról, a więc podjęcie i realizowanie zadań cenionych $\mathrm{w}$ społeczeństwie. $\mathrm{W}$ przypadku pełnienia uznawanych ról społecznych cechy nieakceptowane stają się mniej znaczące i łatwiej tolerowane przez społeczeństwo, a osoba uzyskuje łatwiejszy dostęp do cenionych wartości i dóbr społecznych [Kendrick 1994]. Teoria ta $\mathrm{w}$ swoim wymiarze praktycznym pokazuje i odpowiada również na pytanie jak to zrobić. Waloryzacja roli odbywa się przez dwie strategie działań: poprawianie społecznego wizerunku i zwiększanie kompetencji, które zoperacjonalizowane w programie PASSING (Program Analysis of Service Systems' Implementation of Normalization Goals - Programowa analiza realizacji celów normalizacji w systemach usług) stanowią zestaw strategii i narzędzi gotowych do wykorzystania w praktycznych działaniach opartych na założeniach teorii [Wolfensberger, Thomas 2007].

Teoria waloryzacji ról - zbieżności z koncepcją edukacji włączającej

Pomostem częściowo spajającym teorię waloryzacji ról z filozofią edukacji włączającej jest społeczny model niepełnosprawności [por. Race i in. 2005]. Według społecznego modelu brak lub ograniczenie aktywności człowieka jest spowodowane współczesną organizacją społeczną, w której nie bierze się pod uwagę potrzeb osób z uszkodzeniami i trudnościami w uczeniu się, tym samym wykluczając ich z głównego nurtu życia społecznego [UPIAS, za: Wiliński 2010, s. 17]. Wykluczenie i negatywne doświadczenia życiowe (wounds), jako konstruowane społecznie w teorii waloryzacji roli społecznej, w modelu społecznym stanowią istotę niepełnosprawności - również usankcjonowanej społecznymi przekazami, interpretacjami i barierami [por. Race i in. 2005, s. 515]. Jako podstawa włączania na gruncie edukacji model społeczny traktuje nieprzygotowane środowisko szkolne jako źródło ograniczeń rozwojowych, edukacyjnych, społecznych dla dziecka niepełnosprawnego [por. Zacharuk 2011]. O ile aktualnie pojawia się coraz więcej stanowisk podważających model społeczny w jego skrajnie reduk- 
cjonistycznym wydaniu w płaszczyźnie edukacji ${ }^{1}$ [Low 2001; Lindsay 2003; Reindal 2008], o tyle w teorii waloryzacji ról społeczeństwo z jednej strony wykluczające, z drugiej dające szansę na odczuwany dobrostan (the good things in life), pozostaje głównym regulatorem możliwości życiowych osób niepełnosprawnych [por. Oliver 1999, s. 172].

Skupiając się jednak na punktach wspólnych teorii waloryzacji ról oraz filozofii edukacji włączającej nie sposób pominąć odniesienia w literaturze podkreślające znaczenie dziedzictwa teorii normalizacji, a potem teorii waloryzacji ról w uzasadnieniach reform edukacji w kierunku włączania [Berlach, Chambers 2011; Foreman 2014]. W Polsce zasada normalizacji jako reakcja na praktykę izolowania osób niepełnosprawnych (segregacyjne szkolnictwo specjalne) utorowała drogę pojęciu integracji [Firkowska-Mankiewicz 2010]. Integracja społeczna ponadto uznawana za cel edukacji w placówce ogólnodostępnej w jednym z dwóch wymiarów może być mierzona poprzez dostęp do cenionych ról społecznych w szkole i jako tego kontynuacja - w życiu dorosłym [Szumski 2010, s. 53]. Zasada normalizacji jako nienaruszająca priorytetów ogólnego systemu szkolnego powinna być naczelną dla systemów kształcenia uczniów niepełnosprawnych. „Zasada normalizacji pozwala ustanowić takie rozwiązania w kształceniu niepełnosprawnych, które zapewniają systemowi szkolnemu możliwość realizacji zasady sprawiedliwości w odniesieniu do wszystkich uczniów" [Szumski 2006, s. 170].

Oba konstrukty teoretyczne przeciwstawiają się wykluczeniu społecznemu jako procesowi blokującemu dostęp do cenionych wartości w życiu, z których niewątpliwie istotną jest edukacja. „Włączanie rozpatrywać należy jako proces odpowiadania na różnorodność potrzeb wszystkich dzieci, młodzieży i dorosłych przez redukowanie, czy wręcz eliminowanie, wszelkich form dotykającego ich wykluczenia" [UNESCO, 2009, s. 9]. Teoria waloryzacji roli doskonale wyjaśnia mechanizm wykluczenia jako krytyczne doświadczenie ludzkie niosące długofalowe skutki i jego źródło znajduje w obejmowaniu statusów, które w percepcji społecznej są mało wartościowe. Teoria ta czerpie $\mathrm{w}$ tym miejscu $\mathrm{z}$ teorii ról społecznych i wprowadza pojęcie statusu głównego (master status), który dominuje inne obejmowane przez jednostkę i wpływa na wszystkie role pełnione w jej życiu [Kumar, Theresiakutty 2012, s. 289]. W przestrzeni szkoły taki status przyjmuje słaby uczeń, mało sprawny fizycznie lub uczeń klasy specjalnej [Thomas, Wolfensberger 1999, s. 128]. Zmiana tego statusu jako zapobiegająca wykluczeniu odbywa się dwiema drogami: zwiększenie kompetencji (np. przez rozwijanie mocnych stron i potencjałów ucznia) oraz poprawianie wizerunku (np. przez

\footnotetext{
Krytyka dotyczy nadmiernego socjologizmu tego modelu - pominięcia czynników tkwiących w dziecku, a także interakcji między nimi a środowiskiem jako wyjaśnień dla doświadczanych trudności edukacyjnych. Zarzuca się mu także niewielkie przełożenia na praktykę - jak skonstruować środowisko dostosowane i wygodne dla wszystkich uczniów reprezentujących tak bardzo różne możliwości i potrzeby.
} 
organizowanie szans zaprezentowania swoich umiejętności, podejmowania decyzji, rozwiązywania problemów na forum klasy itp.).

Obie teorie wyraźnie podkreślają znaczenie społecznej percepcji: mentalności i oczekiwań w powstawaniu barier (w edukacji włączającej) i negatywnych doświadczeń życiowych (w teorii waloryzacji ról). Zbyt sztywne, ulokowane w mentalności decydentów oświatowych i nauczycieli, standardy ról społecznych w szkole (rola kolegi, członka społeczności szkolnej, rola ucznia) mogą skutkować dążeniem do wyeliminowania dziecka, które nie jest w stanie im sprostać (np. dziecka niepełnosprawnego) przez przeniesienie do szkoły specjalnej lub permanentnym deprecjonowaniem jego pozycji wśród jednostek psychofizycznie lepiej przystosowanych do pełnienia ról według tak określonych standardów [Papuda--Dolińska 2017, s. 56]. Bariery tkwiące w przekonaniach nauczycieli o szansach powodzenia wspólnej edukacji uczniów sprawnych i niepełnosprawnych również blokują proces wdrażania inkluzji [Boer i in. 2010; Prodanov, Hilendarski 2014]. W teorii waloryzacji ról oczekiwania społeczne przyczyniają się do konformizmu $\mathrm{w}$ wypełnianiu np. ról dewaluowanych przez mechanizm samospełniającej się przepowiedni [Lemay 1999, s. 234]. Wolfensberger [1970, s. 294] postuluje nawet, zważywszy na siłę oczekiwań społecznych, o świadomą ich kontrolę, co przy długiej tradycji filozofii rewalidacyjnej w polskiej pedagogice specjalnej wydaje się obecnie niemożliwe.

Zbieżności między edukacją włączającą a teorią waloryzacji ról ujawniają się także w celach, do jakich prowadzą w swej wersji modelowej obie koncepcje. Celem inkluzji w edukacji jest umożliwienie każdemu dziecku przynależności do edukacyjnej wspólnoty, która uprawomocnia i ceni jego indywidualność [Stainback $\mathrm{i}$ in. 1994, s. 489]. Inkluzja w edukacji jest jednym z aspektów inkluzji społecznej, która jest procesem przeciwstawnym do wykluczenia społecznego. $\mathrm{W}$ teorii waloryzacji roli to właśnie wykluczenie blokuje dostęp do pożądanych dobrodziejstw życiowych dostępnych przeciętnemu człowiekowi. Jednym z takich w tym sensie może być edukacja wysokiej jakości w szkole najbliższej miejsca zamieszkania, bez oderwania od rodziny i środowiska lokalnego. Pytaniem otwartym pozostaje refleksja czy uczestnictwo w ramach „ogólnodostępnej” wspólnoty szkolnej nie jest narażone na inne odmiany społecznej selekcji i dominacji, jeśli, zgodnie z teorią Wolfensbergera, określimy, które role są wartościowe a które nie?

\section{Edukacja włączająca i teoria waloryzacji ról - główne dysharmonie}

Teoria waloryzacji ról jako niepozbawiona ograniczeń wielokrotnie w literaturze socjologicznej i pedagogicznej spotykała się z krytyką [Oliver 1999; Żółkowska 2013]. Główny zarzut dotyczy konieczności asymilacji, niejednokrot- 
nie zrezygnowania $\mathrm{z}$ własnej niezależności $\mathrm{w}$ drodze do osiągnięcia akceptacji społecznej, poczucia normalności czy satysfakcji z życia.

Jedną z istotnych rozbieżności teorii waloryzacji ról i edukacji włączającej jest odniesienie do idei sprawiedliwości społecznej. Edukacja włączająca niejako wyrasta z tej idei, dając prawo wszystkim członkom społeczeństwa do edukacji wysokiej jakości [Shyman 2015], podczas gdy teoria Wolfensbergera w pewnym sensie od różnych jednostek wymaga tego samego - sprostania standardom wyznaczonym przez społeczeństwo w celu osiągnięcia tego co dobre, cenne, normalne. Dodatkowym problemem w tym miejscu wydaje się utożsamienie tego, co społecznie cenione z tym, co indywidualnie cenne, która to zgodność $\mathrm{w}$ wielu sytuacjach jest najzwyczajniej artefaktem. Za jeden z najtrudniejszych dylematów rehabilitacji społecznej uznaje się konflikt dążenia do zajmowania wysokiej pozycji społecznej z niezależnością osobistą osoby niepełnosprawnej. Koszty osobiste przyjęcia pozycji cenionej bywają nieraz zbyt duże (stres związany z brakiem odpowiednich kompetencji, obawy dotyczące zagrożenia utraty pozycji, zmęczenie z powodu wykonywania zadań, które są nieodpowiednie) [Kowalik 2007]. Trudno oszacować, jakie koszy ponosi dziecko niepełnosprawne, któremu proponuje się rolę ucznia szkoły ogólnodostępnej, gdzie wymagania przekraczają jego możliwości. Z pewnością może być to jedna z sytuacji, w której cenione społecznie role i zadania znaczą coś zupełnie odmiennego od cennych dóbr i wartości z perspektywy dobrostanu, rozwoju czy satysfakcji tegoż dziecka.

Truizmem wydaje się fakt, że teoria waloryzacji ról w swoim zasięgu jest zdecydowanie szersza niż filozofia edukacji włączającej, która to nie daje się jednoznacznie wpisać w jej - zdawałoby się - uniwersalne zasady, zapobiegające wykluczeniu. Edukacja w powszechnej szkole ogólnodostępnej dla dziecka niepełnosprawnego może być jednym $\mathrm{z}$ "dobrodziejstw” życiowych (the good things in life) i w pewnym bardzo ogólnym sensie zapobiegać wykluczeniu, tak samo jak przeniesienie go do szkoły specjalnej jest tylko jednym z wielu form dewaluacji (wounds). Istnieje jeszcze jeden rodzaj wykluczenia, który teoria Wolfensbergera w ramach edukacji włączającej de facto tworzy i który dotyczy jednostek z jakiegoś powodu niezdolnych do pełnienia ról cenionych. Nie każdy uczeń niepełnosprawny będzie w stanie pełnić rolę dobrego czy nawet przeciętnego ucznia, życzliwego kolegi, aktywnego członka społeczności szkoły ogólnodostępnej. Czy w związku z tym ma być skazany na społeczną dewaluację?

Jak się okazuje, edukacja włączająca ma zdecydowanie więcej punktów wspólnych ze społecznym modelem niepełnosprawności, podczas gdy teoria waloryzacji ról czerpie z niego jedynie społecznie konstruowany charakter wykluczających przekazów i praktyk. Ich zwalczenie odbywa się poprzez dwa działania: zwiększenie kompetencji i polepszenie wizerunku społecznego, których ciężar spoczywa na osobie dewaluowanej, tu niepełnosprawnej. Takie rozumienie 
społecznego postrzegania niepełnosprawności nadal jest bliższe modelowi indywidualnemu niż społecznemu [por. Barnes, Mercer 2008, s. 8]. Zdaniem Slee [2011] teoria waloryzacji ról podważa naczelną zasadę edukacji włączającej, w której sama różnorodność jest cenną wartością. Nadal mamy tu do czynienia z dominacją pełnosprawnej części społeczeństwa nad mniejszością niepełnosprawnych, choć Wolfensberger raczej demaskuje mechanizm wykluczenia niż dywaguje, na ile jednostka może pozostać sobą, by tego wykluczenia nie doświadczyć.

Teorie te są także rozbieżne w miejscu jednego z dydaktycznych aspektów edukacji włączającej, mianowicie ograniczenia stosowania pomocy specjalnej na rzecz uwspólniania programu kształcenia uczniów pełnosprawnych i niepełnosprawnych. Wolfensberger twierdzi, że „W odniesieniu do niepełnosprawnych należy używać środków, które są możliwie zgodne z kulturowymi normami, po to, aby rozwinąć lub zachować sposoby zachowania się i cechy jednostek, które w możliwie najwyższym stopniu odpowiadają normom kulturowym" [1972, s. 84]. G. Szumski [2006, s. 37] na podstawie tej tezy mówi o sprzeczności pedagogiki specjalnej, choć równie dobrze widać w niej sprzeczność samej teorii waloryzacji ról: nie zawsze podniesienie kompetencji społecznych jest tożsame z ulepszeniem społecznego wizerunku. O ile szkolne działania rewalidacyjne czy nawet sama rehabilitacja niewątpliwie przyczyniają się do podniesienia kompetencji jednostek niepełnosprawnych, o tyle $\mathrm{w}$ pewnych sytuacjach mają charakter stygmatyzujący, często niekorzystnie formujący ich społeczny wizerunek².

Obie teorie różnią się również $\mathrm{w}$ dwóch konstytutywnych dla nich założeniach. Edukacja włączająca zakłada współobecność osób pełnosprawnych i niepełnosprawnych jako pierwszy krok do włączania, społecznej integracji i współpracy, natomiast teoria waloryzacji ról dotyczy także sytuacji, w których ta koegzystencja nie jest konieczna. Po drugie, inkluzja jest procesem budowania nowej normy hołdującej różnorodności i konstruktywistycznej perspektywie powstawania ewentualnych niepowodzeń szkolnych czy samej niepełnosprawności, natomiast teoria waloryzacji ról wykorzystuje normy już społecznie ustalone jako ramy utrzymujące w stanie pożądanym system szkolny.

$\overline{2}$ O konsekwencjach dominacji filozofii rewalidacyjnej pisze A. Krause [2011, s. 151], wymieniając wśród nich m.in. potwierdzenie teorii defektu i odchyłu człowieka niepełnosprawnego. Działania takie wzmacniają społeczne postrzeganie niepełnosprawności jako stanu nieprawidłowego, wymagającego naprawy, ograniczając czas wolny osób niepełnosprawnych i ich uczestnictwo w innych formach życia społecznego. 


\section{Edukacja włączająca przez pryzmat siatki pojęciowej teorii waloryzacji ról}

Teoria waloryzacji ról, choć w wielu istotnych punktach różni się od założeń konstytuujących podstawy teoretyczne edukacji włączającej, dostarcza klarownych wyjaśnień na temat dynamiki wykluczających doświadczeń uczniów z niepełnosprawnością w szkołach specjalnych, jak również szkołach ogólnodostępnych - włączających oraz wprowadza w sferę nieuświadomionych społecznych procesów, które dziejąc się nieoficjalnie definiują jakość edukacyjnej inkluzji. Kluczowymi pojęciami teorii Wolfensbergera, oprócz wykluczenia społecznego, „dobrodziejstw” społecznych, waloryzacji roli, stanowią także tzw. wątki przewodnie (10 themes), które powtarzają się we wszystkich implikacjach teorii, przede wszystkim tych praktycznych [Thomas, Wolfensberger 1999, s. 152-155]. Organizują one teorię i pozwalają na jej bezpośrednie odniesienie do konkretnych sytuacji - w przypadku niniejszych interpretacji będzie to edukacja ucznia niepełnosprawnego w szkole ogólnodostępnej w modelu edukacji włączającej.

Pierwszy wątek (The Role of Unconsciousness) podkreśla rolę (nie)świadomości w procesie wykluczenia i w tworzeniu dewiacji oraz utrwalaniu zależności osób społecznie dewaluowanych. W płaszczyźnie edukacji elementy tego procesu znajdziemy w zestawie pozadydaktycznych konsekwencji uczęszczania do szkoły nazywanych „ukrytym programem” [Meighan 1993]. Większość z nich odciska swoje piętno na społecznym funkcjonowaniu całych grup. W szkołach integracyjnych (podobne zjawiska dotyczą szkół ogólnodostępnych - inkluzyjnych) A. Lis-Kujawski [2008] wyróżnił program ukryty za zachowaniami nauczycieli (wzory postaw nauczycieli wobec niepełnosprawnych: zbytni indywidualizm, specjalne traktowanie itd.), za ocenianiem (stosowanie taryfy ulgowej), za codziennością szkolną (integracja formalna, „pozorna”), za działaniem instytucji (niezaadaptowane budynki, bariery architektoniczne, niewystarczające wykształcenie nauczycieli). Ukrytych przekazów wykluczających uczniów niepełnosprawnych z edukacji ogólnodostępnej na gruncie polskim mamy więcej: selekcja uczniów „nadających” się do kształcenia niesegregacyjnego [Pachowicz 2013], izolacja lub wiktymizacja dzieci niepełnosprawnych w klasach ogólnodostępnych [Maciarz 2000; Plichta, Olempska-Wysocka 2013] czy negatywne postawy nauczycieli wobec wspólnej edukacji dzieci niepełnosprawnych z pełnosprawnymi rówieśnikami [Błeszyńska 1992].

Drugi wątek (Conservatism Corollary) dotyczy pozytywnej kompensacji negatywnych doświadczeń życiowych osoby dewaluowanej. Uczeń niepełnosprawny bardziej niż jego rówieśnicy narażony jest na te doświadczenia w płaszczyźnie społecznej: odrzucanie i izolowanie [Freeman, Alkin 2000; Lipińska-Lokś 2003; 
Wiącek 2008] oraz edukacyjnej: niekorzystna sytuacja porównawcza [Szumski 2010, s. 144] lub niepowodzenia szkolne i wyuczona bezradność [Gindrich 2011]. Kompensacja tych doświadczeń według Wolfensbergera powinna przyjąć formę zadośćuczynienia, zatem zwykłe środki stosowane wobec uczniów pełnosprawnych mogą okazać się tutaj niewystarczające. Doświadczenia odrzucenia czy niepowodzeń szkolnych nie są jednorazowe, więc strategie pomocowe powinny przyjmować formę konsekwentnych, długofalowych działań czy całościowych programów (jak np. tutoring rówieśniczy, coaching dziecięcy, nauczanie kooperacyjne, metoda projektów, ocenianie kształtujące, ćwiczenie poczucia skuteczności etc.).

Wątek trzeci (The Importance of Interpresonal Identification between Valued and Devalued People) łączy się z interpersonalną, wzajemną identyfikacją osób cenionych i dewaluowanych polegającą na dostrzeganiu cech wspólnych. W ten sposób osoby przyjmujące role cenione będą mogły zrozumieć doświadczenia ludzi dewaluowanych, a ci z kolei identyfikować i naśladować ich w dążeniu do cenionych dóbr społecznych. Przekonanie to jest częściowo zgodne z orientacjami teoretycznymi początków niesegregacyjnego kształcenia. Jedną z nich jest teoria wspólnych i swoistych cech charakteryzujących osoby pełnosprawne i niepełnosprawne A. Hulka [1977], w której podkreślał, że w grupach ludzi niepełnosprawnych i pełnosprawnych istnieje znacznie więcej sfer wspólnych niż swoistych i specyficznych. Druga, dotycząca poziomu specjalizacji kształcenia uczniów niepełnosprawnych i z trudnościami w uczeniu się [Norwich, Lewis 2007], wyróżnia wariant wspólnych i indywidualnych potrzeb edukacyjnych, wnosząc głos w dyskusję na temat uwspólniania i różnicowania kształcenia uczniów sprawnych i niepełnosprawnych. Edukacja włączająca w swojej konstrukcji w wielu miejscach podkreśla podobieństwa między członkami wspólnoty klasowej wszyscy uczęszczamy do tej samej szkoły, klasy, realizujemy ten sam program, odrabiamy te same prace domowe, zdajemy te same egzaminy. Stanowi to swego rodzaju zaszyfrowaną, bo nieuświadomioną wiadomość „wszyscy jesteśmy podobni", istotną zarówno dla niepełnosprawnych, jak i pełnosprawnych członków wspólnoty szkolnej. Istnieje gros badań empirycznych potwierdzających wzrost empatii, otwartości, współpracy u dzieci pełnosprawnych w sytuacji wspólnej edukacji z uczniami niepełnosprawnymi [Boyle i in. 2011; Diamond, Carpenter 2000; Aboud i in. 2003; Cameron i in. 2007; Consiglio i in. 2014].

Czwarty wątek (The Concepts of Relevance, Potency and Model Coherency of Measures and Services) kładzie nacisk na trzy najistotniejsze cechy systemów przeznaczonych dla osób dewaluowanych: trafność względem potrzeb, efektywność, wewnętrzna spójność. Rozpatrywanie w kontekście tych cech systemu edukacji włączającej doprowadza do bardzo skrajnych wniosków. Z jednej strony jako model praktycznego działania jest precyzyjnie określony względnie jednoznacz- 
nymi wytycznymi prawnymi o zasięgu globalnym (np. „Kluczowe zasady służące promocji jakości w edukacji włączającej"; Watkins 2009), jak i lokalnym (np. materiały MEN „Edukacja włączająca uczniów niepełnosprawnych”; MEN 2014). $Z$ drugiej strony nie jest to koncepcja na tyle praktycznie zweryfikowana, żeby z pełnym przekonaniem stwierdzić, iż jest ona efektywna. Dokonane do tej pory badania empiryczne, przeglądy i metaanalizy wprowadzają jeszcze silniejszą ambiwalencję w tej kwestii [zob. Staub, Peck 1995; Baker i in. 1994; Tilstone i in. 1998; Freeman, Alkin 2000]. Ponadto, o ile w sporach o charakter i zasadność wdrażania modelu edukacji włączającej pojawiają się różne głosy, to w momencie uznania koncepcji za niejednoznaczną i wielopłaszczyznową wszystkie brzmią jednogłośnie. Przyczyny tego faktu są co najmniej dwie. Po pierwsze, edukacja włączająca pod względem ideowym znacznie wyprzedziła rzeczywistość praktyczną, a „urzeczywistnienie tej koncepcji wymaga zmiany ducha szkoły, mentalności pracujących w niej i korzystających z jej usług ludzi" [Szumski 2010, s. 35]. Po drugie, jest zmianą radykalną wobec dotychczasowych tradycji w kształceniu specjalnym, jak i tradycji teoretycznych (paradygmatycznych) samej dziedziny pedagogiki specjalnej.

Wątek piąty (Reality of Social Imagery and Image Transfer) zwraca uwagę na rolę jawnych i ukrytych przekazów w budowaniu wizerunku osób dewaluowanych. Najczęściej przekazy odnośnie do roli ucznia niepełnosprawnego, ucznia z trudnościami w uczeniu się są nieuświadamiane i dotyczą środowiska fizycznego (np. usadzenie uczniów $\mathrm{z}$ trudnościami $\mathrm{w}$ uczeniu się $\mathrm{w}$ odseparowanym miejscu w klasie), kontekstu społecznego (funkcjonowanie w szkole w otoczeniu nauczycieli wspomagających i terapeutów), zachowań oczekiwanych (np. wolniejsze tempo pracy szkolnej), języka (określenie „uczeń o specjalnych potrzebach edukacyjnych"), prezencji (odmienny wygląd zewnętrzny na skutek niepełnosprawności) [zob. Race 2002, s. 204]. W taki sposób szkoła buduje przekonanie, że uczeń potrzebuje specjalnego traktowania, podkreśla jego inność, stygmatyzuje tworząc skojarzenia z negatywnym wizerunkiem osoby mało zaradnej, potrzebującej pomocy, nieliczącej się, jednym słowem - dewaluowanej. W teorii waloryzacji roli panaceum na ten problem jest kontrola przekazów dotyczących osób niepełnosprawnych na poziomie bezpośrednim, jak i wyższym - społecznym oraz zmiana ich charakteru w stronę obrazów pozytywnych.

Szósty motyw teorii waloryzacji ról (The Power of Mind-sets and Expectancies) podkreśla siłę przekonań oraz oczekiwań, która została przeanalizowana wyżej jako jeden z punktów wspólnych teorii Wolfesbergera i edukacji włączającej. W obu koncepcjach są one przyczyną negatywnych doświadczeń i blokadą dla osiągnięcia dobrostanu czy sukcesu, np. edukacyjnego. Dużym problemem są utrwalone przekonania i obniżone oczekiwania wobec uczniów z niepełnosprawnością ze strony rodziców, dyrekcji, a przede wszystkim osób bezpośrednio zaan- 
gażowanych w kształcenie i wychowanie - nauczycieli. Niektórzy zaniżają wymagania wobec takich uczniów spodziewając się gorszych wyników szkolnych [Courtade i in. 2012], inni nie wierzą w powodzenie wspólnej edukacji w warunkach szkoły ogólnodostępnej [Santoli i in. 2008]. Takie przekonania o swego rodzaju „niewyuczalności” lub „nieintegrowalności” dzieci niepełnosprawnych podważają sensowność organizowania sytuacji edukacyjnych, rozwijającego środowiska, tym samym nie dają szans do rozwoju i pełnienia ról cenionych.

Wątek siódmy (The Communicators of Role Expectancies and the Feedback between them and Role Performance), ściśle związany z szóstym, przyznaje oczekiwaniom społecznym determinującą zachowanie funkcję. Zakłada bowiem, że ludzie zachowują się zgodnie z oczekiwaniami społecznymi i jeśli są one niskie, częściej przyjmują role dewaluowane. Zależność ta jest dwustronna - realizowanie ról wyżej cenionych modyfikuje oczekiwania, gdyż osoba cieszy się pozytywnym wizerunkiem i ma więcej doświadczeń zwiększających jej kompetencje. Zdaniem Rosenthala i współpracowników [Rosenthal i in. 1968] mechanizm ten nie jest cyrkularny i tak oczywisty jak przedstawia go Wolfensberger, a metaanalizy pokazują niewielki wpływ oczekiwań na zmianę zachowania [Jussim 1990]. Zjawisko to obecne jest także w warunkach szkoły i występuje w dwóch odmianach tzw. efektu Pigmaliona. Jak pokazuje empiria, również i w tej płaszczyźnie jego siła jest niewielka, ale za to długotrwała - wpływ oczekiwań nauczyciela może przetrwać nawet kilka lat [Smith i in. 1999]. Choć sama idea edukacji włączającej postuluje równe (ale nie takie samo) traktowanie wszystkich uczniów to oczekiwania, jak i ich przełożenia na działania dydaktyczne i wychowawcze nauczycieli już takie do końca nie są [zob. Bartnikowska i in. 2016].

W wątku ósmym (The Importance of Personal Competency Enhancement) Wolfensberger i Thomas podkreślają znaczenie przeszkód w rozwoju oraz edukacji osób dewaluowanych, a także rozwijania repertuaru ich zdolności, możliwości, potencjałów. W praktyce oznacza to identyfikowanie potrzeb i trafne odpowiadanie na nie $\mathrm{w}$ formie indywidualizujących praktyk, $\mathrm{w}$ omawianym kontekście edukacji włączającej - praktyk edukacyjnych. Zasada indywidualizacji w kształceniu uczniów niepełnosprawnych pojawia się praktycznie we wszystkich dokumentach regulujących zalecenia i wytyczne do wdrażania tego modelu $\mathrm{w}$ praktykę szkolną. Choć jej treść wydaje się jasna, również prowadzi do różnych praktyk [por. Caruso, Osburn 2011, s. 194]. Z jednej strony chodzi o dostosowanie systemu szkolnego do różnorodności uczniów, o uwzględnienie w systemie dydaktyczno-wychowawczym różnic indywidualnych między uczniami i stosowanie takich zabiegów pedagogicznych, które (przy uwzględnieniu owych różnic) sprzyjają maksymalnemu rozwojowi osobowości uczących się [Lewowicki 1977]. Z drugiej, traktowanie indywidualizacji $\mathrm{w}$ wersji focaultowskiej jako zawoalowanego mechanizmu kontroli społecznej [Foucault 1997] może oznaczać wyłonienie „różno- 
rodności", by dopasować ją do ",jednorodności”. O jaką indywidualizację chodzi Wolfensbergerowi, czy taką, która służy indywidualnemu rozwojowi i swego rodzaju emancypacji czy o tą, która w efekcie ma doprowadzić do pełnienia roli cenionej zgodnie z interpretacją społeczną? Nieoczywistość zasady indywidualizacji $\mathrm{w}$ praktyce kształcenia specjalnego sprowadza się do biurokratycznego wypełniania indywidualnych planów edukacyjno-rehabilitacyjnych (IPETów), instrumentalizmu rewalidacyjnego i mnogości zajęć wyrównawczych, kompensacyjnych niedopasowanych do potrzeb uczniów. Konsekwencją tak sformalizowanego i usztywnionego systemu jest albo niska jakość edukacji niedająca szans na dalszy rozwój [Pfahl, Powell 2011], albo osobista porażka dziecka w szkole ogólnodostępnej (również porażka edukacji włączającej) i przeniesienie go do szkoły integracyjnej lub specjalnej [zob. Grzyb 2013].

Wątek dziewiąty (The Power of Imitation and Modeling) podkreśla rolę mechanizmu uczenia się przez modelowanie $\mathrm{w}$ nabywaniu nowych kompetencji i odgrywaniu cenionych ról. Modelem, wzorem do naśladowania powinny być osoby kompetentne i pozytywnie odbierane $\mathrm{w}$ społeczeństwie. Za takie $\mathrm{w}$ warunkach szkoły ogólnodostępnej uchodzą dzieci pełnosprawne w normie rozwojowej. Badania pokazują, że pod kątem społecznym dzieci pełnosprawne wspierają rozwój społeczny dzieci z niepełnosprawnością, stanowiąc wzór prawidłowych zachowań, inicjując kontakt z nimi, podtrzymując i pozytywnie odpowiadając interakcją na interakcję. Uczniowie z niepełnosprawnością szybciej kształtują właściwe umiejętności społeczne $\mathrm{w}$ grupie $\mathrm{z}$ dziećmi zdrowymi niż z innymi rówieśnikami z niepełnosprawnością [Guralnick i in. 1996]. Ponadto wśród strategii nauczania w edukacji włączającej D. Mitchell [2016] popularyzuje uczenie się we współpracy peer tutoring (wzajemne nauczanie) jako oparte na zasadzie imitacji w uczeniu się. O ile skuteczności tego rodzaju uczenia się nie sposób podważyć, to jednak teoria waloryzacji roli jego kierunek traktuje wyraźnie jednostronnie - to osoby dewaluowane czerpią największą korzyść naśladując te bardziej kompetentne i o lepszym wizerunku społecznym. Podejście takie wpisuje się w uproszczoną, przystosowawczo-adaptacyjną wersję koncepcji integracji czy włączania, w której chodzi głównie o „[...] przygotowanie osoby niepełnosprawnej do funkcjonowania w warunkach pełnosprawności i pełnienia ról wyznaczanych przez jej kryteria" [Krause 2011, s. 158].

Dziesiąty, ostatni już wątek (The Importance of Valued Social Participation and Personal Social Integration) mówi o tym, że im pełniejsze uczestnictwo w życiu społecznym tym większy przyrost kompetencji i towarzysząca mu zdolność pełnienia uznawanych ról. Ponadto, jeśli ta społeczna integracja jest odbierana pozytywnie przez asymilującą część społeczeństwa, np. ludzi pełnosprawnych, to prawdopodobnym jest, że będą oni bardziej tolerancyjni i akceptujący względem osób dewaluowanych. Wolfensberger i Thomas podkreślają, że chodzi 
o pełną integrację, a nie jedynie fizyczne ulokowanie jednej grupy w otoczeniu drugiej. W przeniesieniu na grunt edukacyjny pełne uczestnictwo uczniów niepełnosprawnych w życiu społecznym klasy powinno odbywać się na zasadach integracji społecznej, nie zaś jedynie fizycznej [Dykcik 2005]. Ponownie jednak dostrzegalny jest asymilacyjny charakter tego procesu - dominująca większość (uczniowie pełnosprawni) aktywizuje proces włączania i kieruje nim, podczas gdy mniejszość (uczniowie niepełnosprawni) dostosowuje się do panujących warunków i układu ról, jeśli nie, naraża się na dystans i izolację.

\section{Podsumowanie}

Szczegółowość, z jaką teoria waloryzacji ról wyjaśnia proces wykluczenia i powstające $w$ jego efekcie przykre doświadczenia życiowe, stwarza szeroki potencjał interpretacyjny $\mathrm{w}$ analizie szkolnego funkcjonowania dziecka $\mathrm{z}$ niepełnosprawnością w warunkach edukacji włączającej. Jej główną zaletą jest opisowy charakter - waloryzacja roli opisuje pewne wymiary rzeczywistości i określa prawdopodobne rezultaty podejmowania lub zaniechania pewnych działań [Wolfensberger, Tullman 1982]. Traktując klasę szkolną jako miniaturę szerszego społeczeństwa [Brzezińska 1996, s. 208] nietrudno odnaleźć w niej pewien uniwersalny porządek, elementy strukturalne, procesy grupowe i społeczne wyraźnie określone $w$ teorii waloryzacji ról. Nietrudno też o zidentyfikowanie wykluczenia społecznego, jako że cechy związane z niepełnoprawnością rzadko kiedy, na gruncie szkolnym, pokrywają się z charakterystykami uczniów pełniących role cenione: zdolnych, zsocjalizowanych itd. Wyjaśniając proces wykluczenia i defaworyzacji teoria ról społecznych dostarcza wskazówek, strategii do działań praktycznych mających na celu podniesienie statusu ucznia niepełnosprawnego w klasie oraz uzyskanie dostępu do cenionych (cennych?) wartości szkolnego życia. Pytaniem, na które teoria Wolfensbergera odpowiada niestety przecząco, jest to czy ów dostęp nie powinien być należny temu uczniowi jako pełnoprawnemu członkowi szkolnego kolektywu a priori? Przecież edukacja włączająca nie stawia warunków, daje prawo do równej edukacji, a nie prawo do jej osiągnięcia. Z drugiej strony nie sposób pominąć aktualnego wciąż modelu społeczeństwa, także szkoły, w których definicja normalności szerzej lub węziej pojmowana jest socjalizacyjnie przekazywaną "osią dyscyplinującą" dzielącą behawioralne ekstrema wywołujące społeczny podziw lub odrzucenie. Trudno zaprzeczyć temu, że osoba niepełnosprawna, jak każdy inny członek społeczeństwa, powinna wykazać się pewnymi umiejętnościami adaptacyjnymi. „Może rzeczywiście jest tak, że by „normalnie" funkcjonować - integracja wymaga nauki i zaadaptowania się do ży- 
cia w szerokiej społeczności?" pyta A. Krause [2011, s. 163]. Jeśli w perspektywie jednostki zadowolenie $\mathrm{z}$ życia jest równoznaczne $\mathrm{z}$ funkcjonowaniem $\mathrm{w}$ ramach społecznie określonej normalności to kolejnym pytaniem pozostaje to czy warto rezygnować z narzędzi jakie daje teoria waloryzacji ról tylko dlatego, że postuluje adaptację raczej niż emancypację lub może inaczej - emancypację w adaptacji? Ponadto, edukacja włączająca daje szansę na przedefiniowanie cenionych wartości życia szkolnego, a prowadząc działania na rzecz „rozszerzania normalności” pozwala paralelnie zjednać się procesom waloryzacji ról i utrzymywania niezależności osobistej.

\section{Bibliografia}

Aboud F., Mendelson M., Purdy K. (2003), Cross-race peer relations and friendship quality, „International Journal of Behavioral Development", 27(2).

Armstrong J. (2006), The Application of Social Role Valorization in Supporting People with an Intellectual Disability - An Overview, http://www.socialrolevalorization.com/images/documents/ Articles-resources/Armstrong2006-SRVandIntellectualDisability.pdf [dostęp: 2.08.2017].

Baker E.T., Wang M.C., Walberg H.J. (1994), The effects of inclusion on learning, „Educational Leadership", 52(4), s. 33-35.

Barnes C., Mercer G. (2008), Niepetnosprawność, Wydawnictwo SIC, Warszawa.

Bartnikowska U., Ćwirynkało K., Żyta A. (2016), Nauczyciele szkoty integracyjnej wobec kształcenia dzieci z trudnościami emocjonalnymi i w zachowaniu, „Niepełnosprawność. Dyskursy Pedagogiki Specjalnej", nr 23, s. 133-145.

Berlach R.G., Chambers D.J. (2011), Inclusivity imperatives and the Australian national curriculum, "The Educational Forum", 75(1), s. 52-65.

Błeszyńska K. (1992), Determinanty przystosowania ucznia niepetnosprawnego do środowiska szkoty masowej [w:] Uczeń niepetnosprawny w szkole masowej, red. A. Hulek, B. GrochmalBach, Wydawnictwo Naukowe WSP, Kraków.

Boer A., Pijl S.J., Minnaert A. (2010), Regular primary schoolteachers' attitudes towards inclusive education: a review of the literature, "International Journal of Inclusive Education”, 1, 23, s. 1-23.

Boyle C., Scriven B., Durning S., Downes C. (2011), Facilitating the learning of all students: The 'professional positive' of inclusive practice in Australian primary schools, "Support for Learning", 26(2), s. 72-78.

Brzezińska A. (1996), Model edukacji dla obywatelskiej wspótpracy i interwencja edukacyjna wspomagająca społeczność lokalna [w:] Podmiotowość społeczności lokalnych: praktyczne programy wspomagania rozwoju, red. R. Cichocki, Wydawnictwo Fundacji Humaniora, Poznań.

Cameron L., Rutland A., Brown R. (2007), Promoting children's positive intergroup attitudes towards stigmatized groups: Extended contact and multiple classification skills training, „International Journal of Behavioral Development", 31, s. 454-466.

Caruso G.A., Osburn J.A. (2011), The Origins of "Best Practices" in the Principle of Normalization and Social Role Valorization, "Journal of Policy and Practices in Intellectual Disability Research", 8(3), s. 191-196. 
Consiglio A., Guarnera M., Magnano P. (2014), Representation of Disability. Verification of the Contact Hypothesis in School, Procedia - Social and Behavioral Sciences, 191.

Courtade G., Spooner F., Browder D., Jimenez B. (2012), Seven reasons to promote standardsbased instruction for students with severe disabilities: A reply to Ayres, Lowrey, Douglas, \& Sievers (2011), "Education and Training in Autism and Developmental Disabilities", 47(1), s. 3-13.

Diamond K.E., Carpenter C. (2000), The influence of inclusive preschool programs on children's sensitivity to the needs of others, "Journal of Early Intervention", 23.

Dykcik W. (2005), Problemy autonomii, integracji społecznej i normalizacji życia osób niepetnosprawnych w środowisku [w:] Pedagogika specjalna, red. W. Dykcik, Wydawnictwo Naukowe UAM, Poznań.

Firkowska-Mankiewicz A. (2010), Co nowego w edukacji włączajacej, „Edukacja”, nr 2.

Foreman P. (2014), Introducing inclusion in education [w:] Inclusion in action, red. P. Foreman, M. Arthur-Kelly, Melbourne, VIC: Cengage.

Foucault M. (1997), The Ethics of the Concern for Self as a Practice of Freedom [w:] J.D. Faubion, Ethics, Subjectivity, and Truth: Essential Works of Foucault, 1954-1984, The New Press, New York.

Freeman S., Alkin M. (2000), Academic and Social Attainments of Children with Mental Retardation in General Education and Special Education Setting, "Remedial and Special Education”, 1, s. 3-18.

Gause C.P. (2011), Diversity, Equity, and Inclusive Education: A Voice from the Margins, Sense Publishers, Rotterdam.

Gindrich P. (2011), Psychospoteczne korelaty wyuczonej bezradności młodzieży gimnazjalnej $z$ trudnościami w uczeniu się i zaburzeniami towarzyszacymi, UMCS, Lublin.

Grzyb B. (2013), Uwarunkowania zwiąane z przenoszeniem uczniów niepetnosprawnych ze szkót integracyjnych do specjalnych, Oficyna Wydawnicza „Impuls”, Kraków.

Guralnick M.J., Gottman J.M., Hammond M.A. (1996), Effects of social setting on the friendship formation of young children differing in developmental status, "Journal of Applied Developmental Psychology", 17, s. 625-651.

Hulek A. (1977), Wspólne o swoiste zagadnienia w rewalidacji różnych grup osób z odchyleniami od normy [w:] Pedagogika rewalidacyjna., red. A. Hulek, PWN, Warszawa.

Jussim L. (1990), Social reality and social problems: The role of expectancies, "Journal of Social Issues", 46(2), s. 9-34.

Kendrick M. (1994), Some reasons why Social Role Valorization is important. SRV-VRS, „The International Social Role Valorisation Journal", 1, s. 14-18.

Kerzner Lipsky D., Gartner A. (1996), Inclusion, School Restructuring, and the Remaking of American Society, „Harvard Educational Review”, 66(4), s. 762-797.

Kowalik S. (2007), Psychologia rehabilitacji, WAiP, Warszawa.

Krause A. (2011), Wspótczesne paradygmaty pedagogiki specjalnej, Oficyna Wydawnicza „Impuls”, Kraków.

Kumar A., Singh R.R., Theresiakutty A.T. (2015), Normalization vs Social Role Valorization: Similar or Different?, „International Journal of Special Education”, 30(3).

Kumar A., Theresiakutty A.T. (2012), Social Role Valorization (SRV) a Strong Voice of Disability, „Scholarly Research Journal for Interdisciplinary Students", 1(2), s. 284-293. 
Lemay R. A. (1999), Roles, identities, and expectancies: Positive contributions of role theory to Normalization and Social Role Valorization [w:] A quarter-century of Normalization and Social Role Valorization: Evolution and impact, red. R.J. Flynn, R.A. Lemay, ON: University of Ottawa Press, Ottawa.

Lewowicki T. (1977), Indywidualizacja ksztatcenia. Dydaktyka różnicowa, PWN, Warszawa.

Lindsay G. (2003), Inclusive education: a critical perspective, „British Journal of Special Education", 30(1), s. 3-12.

Lipińska-Lokś J. (2003), Psychospołeczna sytuacja dzieci z niepetnoprawnościq intelektualna w klasach integracyjnych [w:] Człowiek z niepetnosprawnością intelektualna, t. 1. red. Z. Janiszewska- Nieścioruk, Oficyna Wydawnicza „Impuls”, Kraków.

Lis-Kujawski A. (2008), Moje „ja” i szkoła integracyjna, Oficyna Wydawnicza „Impuls”, Kraków.

Low C. (2001), Controversial speech by British activist: Have disability rights gone too far?, „Disability World", 7, March-April.

Maciarz A. (2000), Nadzieje i obawy związane z reforma szkolnictwa specjalnego, „Szkoła Specjalna", nr 1.

Meighan R. (1993), Socjologia edukacji, UMK, Torun.

Ministerstwo Edukacji Narodowej (2014), Edukacja włączająca uczniów niepetnosprawnych, Warszawa.

Mitchell D. (2016), Sprawdzone metody w edukacji specjalnej i właczającej. Strategie nauczania poparte badaniami, Harmonia, Gdańsk.

Nirje B. (1969), The normalization principle and its human management implications [w:] Changing patterns in residential services for the mentally retarded, red. R. Kugel, W. Wolfensberger, President's Committee on Mental Retardation, Washington D.C.

Norwich B., Lewis A. (2007), How specialized is teaching children with disabilities and difficulties?, "Journal of Curriculum Studies", 39(2), s. 127-150.

Oliver M. (1999), Capitalism, disability and ideology: a materialist critique of the normalization principle [w:] A quarter-century of normalization and social role valorization: evolution and impact, red. R. Flynn, R. Lemay, University of Ottawa Press, Ottawa.

Pachowicz M. (2013), Próba wyjścia z rezerwatu. O paradoksach ukrytych w edukacji i rehabilitacji osób niepetnosprawnych [w:] Człowiek z niepetnosprawnością w rezerwacie przestrzeni publicznej, red. Z. Gajdzica, Oficyna Wydawnicza „Impuls”, Kraków.

Papuda-Dolińska B. (2017), Dziecko z niepetnosprawnością wzroku w roli ucznia szkoły ogólnodostęnej integracyjnej i specjalnej, UMCS, Lublin.

Perrin B., Nirje B. (1985), Setting the record straight: a critique of some frequent misconceptions of the normalization principle, „A Australia \& New Zealand Journal of Developmental Disabilities", 11, s. 69-74.

Pfahl L., Powell J.J. W. (2011), Legitimating school segregation: The special education profession and the discourse of learning disability in Germany , „Disability \& Society”, 26(4), s. 449-462.

Plichta P., Olempska-Wysocka M. (2013), Narażenie na agresję rówieśnicza niepełnosprawnych uczniów szkót integracyjnych w relacjach nauczycieli wspomagajacych, "Studia Edukacyjne”, 28, s. 169-190.

Prodanov M., Hilendarski P. (2014), Stereotypes as Stigmatizing Barriers to Effective Inclusive Education, "International Journal on New Trends in Education and Their Implications", 5(2), s. 169-177. 
Race D. (2002), Learning Disability: A Social approach, Routledge, London.

Race D.G. (1999), Social role valorization and the English experience, Whiting \& Birch Ltd., London.

Race D., Boxall K., Carson I. (2005), Towards a dialogue for practice: Reconciling Social Role Valorization and the social model of disability, "Disability \& Society”, 20(5), s. 507-521.

Reindal S.M. (2008), A Social Relational Model of Disability: A Theoretical Framework for Special Needs Education?, „European Journal of Special Needs Education”, 23(2), s. 135-146.

Rosenthal R., Jacobson L. (1968), Pygmalion in the classroom: Teacher expectation in the Classroom, Holt, Rinehart \& Winston, New York.

Santoli S.P., Sachs J., Romey E., McClurg S. (2008), A successful formula for middle school inclusion: Collaboration, time, and administrative support, "Research in Middle Level Education", 32(2), s. 1-13.

Shyman E. (2015), Toward a globally sensitive definition of inclusive education based in social justice, „International Journal of Disability, Development and Education”, 62(4), s. 351-362.

Slee R. (2011), The irregular school: Exclusion, schooling and inclusive education, Taylor \& Francis, New York.

Smith A.E., Jussim L., Eccles J. (1999), Do self-fulfilling prophecies accumulate, dissipate, or remain stable over time?, "Journal of Personality and Social Psychology", 77, s. 548-565.

Stainback S., Stainback W., East K., Sapon-Shevin M. (1994), A commentary on inclusion and the development of a positive self-identity by people with disabilities, "Exceptional Children", 60(6), s. 486-490.

Staub D., Peck C.A. (1995), What Are the Outcomes for Nondisabled Students?, „Educational Leadership", 52(4), s. 36-40.

Szumski G. (2006), Integracyjne kształcenie niepetnosprawnych, PWN, Warszawa.

Szumski G. (2010), Wokót edukacji włączającej. Efekty kształcenia uczniów z niepetnosprawnościq intelektualna $w$ stopniu lekkim w klasach specjalnych, integracyjnych i ogólnodostępnych, Wydawnictwo APS, Warszawa.

Thomas S., Wolfensberger W. (1999), An overview of Social Role Valorization [w:] A QuarterCentury of Normalization and Social Role Valorization: Evolution and Impact, red. R.J. Flynn, R.A Lemay, University of Ottawa Press, Ottawa.

Tilstone C., Florian L, Rose R. (1998), Promoting Inclusive Practice, Routledge, London.

UNESCO (2009), Policy Guidelines on Inclusion in Education, UNESCO, Paris.

Watkins A. (red.) (2009), Kluczowe zasady stużące promocji jakości w edukacji włączającej, Europejska Agencja Rozwoju Edukacji Uczniów ze Specjalnymi Potrzebami, Bruksela.

Wiącek G. (2008), Efektywna integracja szkolna. Systemowy model uwarunkowań powodzenia w kształceniu integracyjnym, Towarzystwo Naukowe KUL, Lublin.

Wiliński M. (2010), Modele niepetnosprawności: indywidualny - funkcjonalny - społeczny [w:] Diagnoza potrzeb i modele pomocy dla osób z ograniczeniami sprawności, A.I. Brzezińska, R. Kaczan, K. Smoczyńska, Wydawnictwo Naukowe Scholar, Warszawa.

Wolfensberger W. (1970), The principle of Normalization and its implication for psychiatric Services, „American Journal of Psychiatry”, 127, s. 291-297.

Wolfensberger W. (1972), The principle of normalization in human services, National Institute on Mental Retardation, Toronto-Canada. 
Wolfensberger W., Thomas S. (2005), Introductory Social Role Valorization workshop training package. Syracuse, Training Institute for Human Service Planning, Leadership and Change Agentry, New York.

Wolfensberger W., Thomas S. (2007), PASSING. A tool for analyzing service quality according to Social Role Valorization criteria. Ratings manual (3rdrev.ed.), Training Institute for Human Service Planning, Leadership, \& Change Agentry (Syracuse University), New York.

Wolfensberger W., Tullman S. (1982), A brief overview of the principle of normalization, „, Rehabilitation Psvchology", 27(3), s. 131-145.

Zacharuk T. (2011), Edukacja włączająca szansa dla wszystkich uczniów, „Meritum”, 1(20).

Żółkowska T. (2013), Społeczna (de)waloryzacja roli osoby niepetnosprawnej [w:] Człowiek z niepetnosprawnościa w rezerwacie przestrzeni publicznej, Z. Gajdzica, Oficyna Wydawnicza „Impuls”, Kraków. 